\title{
ONLINE SALE AS A SUBFUNCTION OF INTERNET MARKETING
}

\author{
Milan Gašović ${ }^{1}$ \\ Almir Muhović2 \\ Nikola Ćurčić,
}

\author{
${ }^{1}$ Singidunum University, \\ 32 Danijelova Street, Belgrade, Serbia \\ ${ }^{2}$ University Union - Nikola Tesla, \\ Faculty of Construction Management, \\ Belgrade, Serbia \\ ${ }^{3}$ University Union - Nikola Tesla, \\ Faculty of Management, \\ Sremski Karlovci, Serbia
}

\section{Correspondence:}

Milan Gašović

e-mail:

mgasovic@singidunum.ac.rs

\begin{abstract}
:
In the traditional sense, sales imply a set of activities and tasks undertaken by companies to realise the selling of products and services. According to the marketing business orientation, a sale is the final marketing program of the given company. Modern companies implement marketing activities, including sales over the Internet as a powerful global media. This has led to a theoretical and practical shaping of Internet marketing as a new marketing form. In accordance with the concept of Internet marketing, selling becomes a sub-function of Internet marketing, that is, online sales.
\end{abstract}

Key words:

online sales, internet marketing; online presentations, online negotiation; sales web site

\section{INTRODUCTION}

A sale as an operational business function, either independently or in the context of marketing sector, provides companies with previously established market segments. It connects marketing system with the customers it serves. From it derives its ability to survive, develop and grow.

In accordance with the marketing way of business and sales, it adjusts the efforts of seller to the needs of customers and indicates to customers that sellers are ready and willing to meet their demands.

In recent decades, traditional marketing concept has received support in the form of Internet marketing or online marketing. Internet marketing includes online sales, as its sub-function through which the needs of online customers / consumers are met

In fact, online sales use the approach that offers direct, traditional sales, dependent on the growth and development of telecommunications and information technology (IT). Thanks to the strong technical basis, companies can achieve more direct relationship with their customers. Companies can now contact their customers directly - without intermediaries, so that they can respond to their needs, wishes and special requests. The point is that these consumers are not just anybody. They have been reached through online research, so they have been identified as potential buyers or services users, enabling the creation of their data base. The offer to which the precisely defined target customer can answer is created on this basis. 
The sale, as a sub-function of Internet marketing or online sales, assumes the maximum automation of the sales process with the use of information technology. The goal is to enable customers and service users to select all the items of their order through the Web site, in an easy and simple way, at time that suits them, so they can then settle their financial obligations through electronic payments.

An online sale assumes the creation of a company's Web site on the Internet. At the same time, it is necessary to meet a number of primarily marketing demands. By completing the given requests, it is possible to achieve the effectiveness of the Internet marketing as a whole and raise online sales to a higher level in that context.

The whole process of online sales, viewed from the aspect of IT support, can be viewed through the phases such as: online sales presentation, online sales negotiation, integration of online sales with storage and delivery, connection with other online activities, etc.

\section{INTERNET MARKETING AS A FRAMEWORK FOR ONLINE SALES}

Modern companies perform a lot of activities on the Internet, among which it is not difficult to identify those that belong to the field of marketing. These are: communication and promotion, marketing research, distribution, sale, etc. There are also two specific activities for a new form of marketing called Internet marketing. These are the activities offering content (Content Providing) and enabling networking (Network) (Jović, M., 2012).

Traditional marketing concept also receives support in the form of Internet marketing. As the Internet is an interactive medium that relies on two-way communication in which all stakeholders can participate actively, it can be said that the support to the traditional principles of marketing is achieved through the use of methods of interactive marketing. The result of such a combination is the fourth principle of the marketing concept, which complements the three already widely accepted concepts of value creation for customers, competitive advantage obtention and guiding objectives, resources and activities on a strategic basis.

A part of the overall marketing efforts invested by companies in order to meet the three traditional requests should be directed towards fulfillment of the fourth principle, which is to satisfy the specific demands of online customers. Thus, Internet marketing is integrated into the overall marketing concept of the com- pany. Starting from the given approach, the total marketing concept of the company consists of traditional marketing concept (offline), and modern marketing concept (online).

Those principles are compatible with the so-called Internet marketing model, known as the $4 \mathrm{C}$ model. Model $4 \mathrm{C}$ is based on the four pillars of Internet marketing: content (Content), users' path (Clickstream), Communication (Communication), Conversion (Conversion). (Mayer, D., Johnston, K., Eliis-Chandwich, F., 2000)

- Content (Content) on the Web site, its setting and the concept form the basis of quality online performances of companies. The peculiarity and the designed setting of the content provide easier achievement of the Internet Marketing objectives.

- The Users' path (Clickstream) allows monitoring of activities of companies' Web sites visitors. The analysis of the visitors' path reveals where the visitors came from, where they were moving and when they left. It allows the interaction with potential customers or service users.

- Communication (Communication) is aimed at more efficient realization of the key objectives of online marketing activities, such as finding new customers / clients and improvement of direct sales. It is based on the content and users' path.

- The conversion (Conversion) enables precise expression of conversion of Web site visitors into the users, i.e. customers.

An online sale as a sub-function of Internet Marketing has the support from other online sub-functions such as online marketing research and online promotion and online aspects of distribution.

The main objective of online research is identification of current and potential customers based on the volume, dynamics and quality of completed purchases, domain of interest, announced shopping, etc. Information technology supports all forms of marketing research. Questionnaires are sent electronically as e-mail surveys.

On the basis of the given information, it is easier to define the target groups for promotional online campaigns. Online advertising may be appropriate to send adequate messages to interested buyers. Companies connect their e-mail addresses with standard search engines (Yahoo, Google, Northlight), thus increasing the number of visits to their Web sites.

Online sales, through information technology, are integrated with the storage and delivery of products sold, i.e. with the online aspects of distribution. In other 
words, verification of inventories, orders from customers and monitoring of deliveries to customers is performed automatically.

All of these sub-functions of Internet marketing provide support to online sales and directly contribute to its performance.

\section{THE NATURE OF ONLINE SALES}

A sale as a sub-function of Internet marketing or online sales assumes the maximum automation of the sales process with the use of information technology. This allows customers to select all the items for their order in an easy and simple way, at the time it suits them, and that they can settle their financial obligations through electronic payments. In doing so, the given company is directly or indirectly associated with a financial institution, that is connected to the financial system. This way of sales is very important because the online market is an inexhaustible source for finding potential buyers.

Informatics also supports automatic management of the process of delivery, providing sales staff with the ability to monitor the status of the stock, and providing customers with the ability to monitor implementation of their orders and transportation of goods that were ordered and paid for.

Information technology support enables forming the customers' database, as well as detailed and accurate profile of each customer, which remains available to all employees in the given company.

Online sales allow reduction of costs of sales while increasing sales volume, which significantly affects the profits of companies. First of all, there are no costs of visits to remote customers.

The effectiveness of online sales depends heavily on the quality of products and services offered, as well as on ancillary services such as guarantees, the possibility of refunds, advice and recommendations to customers, etc.

Potential retail market which can be accessed via the Internet is huge. In addition, there are no number of market segments that are poorly covered with the traditional sales activities. They can offer more adequate products, i.e. the specific requirements of target customers or target groups can be met.

Prices of products and services are the most sensitive elements of the marketing mix on the Internet. The most suitable products and services for online sales are those of mid-level price, as well as those whose price is rapidly changing.
From the aspect of online customers, the most reliable supplier is the producer itself, i.e. a company that sells its own products. The second best option is some kind of exclusivity in the sale. If there is none of the two variants, then it is necessary to have a reliable supplier and solid agreement on the price, quality and delivery.

The convenience of online sales is tied to the costs of storage and delivery, which must be small compared to the prices of the products.

Online sales increase the number of customers of a company and create customers' community. Community is created by an e-mail, by sending electronic news (newsletter) to interested buyers, communication with newsgroups, etc. The famous slogan which can be heard or read in the media in recent years reads: "Create a community and then do the sales". (Mayer, D., Johnston, K., Eliis-Chandwich, F., 2000).

Ideal products for online sales are those that are rich in information (information rich product). It is necessary to create a company's website, as an effective instrument of online sales.

\section{DESIGNING THE SALES WEB SITE}

Designing the Sales Web Site is the last stage in the preparation period before the announcement of the presence of the company on the Internet. It is necessary to meet a number of requirements, as to structure a clear path from the initial to the final Web page with the purchase order for the purchase of products.

Article requirements for creating a selling web site are marketing requirements. By meeting the given requirements, it is possible to achieve the effectiveness of Internet marketing as a whole and increase the sales to a higher level within this framework.

Creating a web site aligns with the marketing profile of Internet customers or service users. At the same time, it is necessary to know their needs and their "Web soul." (Pocajt, I., Tošić. B., 2003) Therefore, we must take into account the following:

- A large number of visitors leave the web site, if its appearance is slow

- Disconnect and bad telephone lines adversely affect the mood of visitors

- Vast web site refuses visitors

- The visitor usually saves Internet time and wants to perform as much work on the given web site.

- Also, it is necessary to: 
- Facilitate finding of the desired information - offer article mechanism for the search of web pages (local Search Engine)

- Offer complete information about products or services, in terms of comparative list of prices, quality competition, information on procurement, etc.

Web communication is impersonal because the visitor does not see the seller. It is therefore necessary to create the impression of natural communication. Therefore, the web page text should be informal, meaning that it should be written as they talk to customers in a direct confrontation with the seller. Specifically, through the website, the visitor has to "see" the real, everyday people, not an abstract company, without the emotional colouring. To choose the right words for texts means to avoid fatigue construction of expression. It should also omit redundant adjectives, highly specialized, academic, jargon words and similar.

Words are the primary means by which the Web site "sells". A visitor usually hurries, so usually passes over the headlines by sight and highlighted parts of the text. The titles are most read, so they can make an important contribution to the potential of selling through the web site. It should be borne in mind that the computer displays a small "shop window" where lots of things need to be presented. Each web page should indicate and call to action that leads to sales.

A basic, introductory page of the sales Web site should inform the visitor on the content of the site and persuade the visitor to look at other web pages. Therefore, it is necessary to complete each web page with the text that calls for viewing the following web pages.

One of the techniques of writing texts for sale sites is asking questions and providing answers. The reason is that questions stimulate interest and attract more attention. Answers contained in the text of a Web page should express the benefits for the customer related to the purchase of a product.

Internet visitors are distrustful by nature, considering the intangibility of the products created by this global medium. It is therefore necessary to gain their trust. The first step in attracting visitors is a well-designed, attractive site design and pleasant atmosphere it emits. Providing your own domain name and clear Web address, simple and compelling, is easy to remember and inspire confidence. Web address should be original, without words and characters that are difficult to pronounce. Balanced, evocative name as the main part of the site, is an important part of the image of the company (Gašović, M., 2010)
This web site contains useful information representing the value for visitors. High quality and rich content builds trust in the web site and makes the given company competent in the eyes of visitors, giving them a chance to learn something new and return to the web site again.

Visitors of the site need the content that will make them satisfied. Web content which is seen as valuable by the visitor must be very versatile. The main content is the concise text that represents the product or service. Necessary part of the content is the text that explains the benefit the customer has of a product and the advantages in relation to the relevant competition product.

In the context of content related to the presentation of the company itself, there are also data on its management. At the same time, it is not recommended to write the best about your company, but one should avoid boasting and empty, propaganda phraseology. Also, one should not brag about these things that are not their possession and should not promise what cannot be fulfilled.

The part of a good Web content is the opinion of the customer about the product being sold, because it is convincing praise of others. Product photos are an important part of Web content.

By organizing Internet forums, iChat rooms, visitors of the site have the opportunity to exchange experiences and to bring them closer to the decision on the purchase of the product. (Milićević, V., 2002).

Once a visitor views a web site and, guided by quality content and a pleasant atmosphere, make a decision on the purchase online, the question is how to realize this? In this regard, it is essential that web site has a form that the visitor fills out and thus, directly orders the product. The form should be clear and concise, with a minimum of required data. Upon receiving the confirmation that the form is received and processed, it is mandatory to send a brief e-mail to the visitor. In the case that the customer decides to buy a larger quantity, it is possible to introduce the so-called virtual consumer shopping cart. Call for online purchase on each side of the web site and shopping cart, as a way of selecting the type and quantity of the product with only one click on the mouse, ensures sales success. (Pocajt,V.,Tošić,D.,2003)

If a company decides to make a web site, it can provide the ability to pay the ordered products by credit card. It is necessary to install a system for secure electronic exchange of critical data (secure server) on the web site. It is about data such as credit card number, customer authorization codes and online financial transactions.

Online sales provide detailed product information, accurate product selection, ease of operation, etc. Cus- 
tomers should always be allowed to withdraw from the selection of a product or shopping in general, to change the selected quantity and similar. Also, they must be provided with a clear insight into the cost of products. In this way, they are encouraged to shop online rather than be forced to buy the product immediately.

It is very important that customers can check numerous testimonies on web pages. They must be sure that any information from the site content can be checked by phone, e-mail, or in the traditional way.

\section{ONLINE SALES PROCESS}

The whole process of online sales, in terms of IT support, can be viewed through the following phases:

- Sales presentations of products and services

- Online sales negotiations

- Integration of sales to storage and delivery

- Connecting to other online marketing activities

- Connecting to other stakeholders in the electronic form

This process of online sales must possess the customer service (Gašović, M., 2010).

Online sales presentation of products or services consists of: a set of products/services, prices, incentives, exchangeability, structuring and search.

A set of products/services is provided by their quantitative expression, display, and monitoring, recording and daily automatic update of assortment that is offered to online customers.

Price indicates the manner in which they are formed, such as according to groups of customers or otherwise. Different customer groups respond differently to price: there is a possibility of forming a promotional price, discounts and similar.

Stimulations suggest that members of a club can have certain benefits, additional packages of products with reduced cost and similar. When selling wholesale, there is a possibility of providing discounts on the amount or quantity rebate.

Exchangeability expresses the intention of the seller to make a substitution of one product for another, if it suits the customer.

- Structuring allows categorization of products.

- Search provides the browse of online product catalogue.

Online sales negotiation include: personalization of sales, sales automation, dialogue with customers, 24hour availability, diversity of modalities of sales, etc.
- Personalization of sales indicates that the company addressed the buyer as a persona, which means that the ratio of 1:1 is formed.

- Sales force automation means accepting and processing orders through the shopping cart, shopping basket and similar. At the same time, the maximum amount of items per order is defined. Also, there are financial transactions, such as the calculation of taxes, transportation costs, methods and types of payments, etc.

- The dialogue with customers provides the possibility of communication between buyers and sellers, thereby securing the additional information.

- 24-hour availability of the use of the site gives customers the option of ordering products when it suits them.

- The diversity of modalities of sales means that it is possible to create online shops, auctions, sales, etc.

Integrating online sales with storage and delivery provides inventory checks, which creates automated ordering and delivery tracking.

Checking the inventory provides the offer of products that are available. Bids must be established in the minimum and maximum amounts.

- Automatic order allows alert, i.e. the fastest response of the company - supplier.

- Monitoring of delivery provides an update of delivery, information on the state of delivery, delivery planning, etc.

- Customer service enables: technical support, localization, feedback, etc.

Processing of all data created in the process of online sales in terms of: metrics business profile and networking with other actors. Metrics operations generate reports on number of visits, realized turnover; assess the effects of discounts and special offers. Profiles of users / customers include all visitors, sales history, predictions etc. Connecting with other stakeholders in terms of exchanging business information and documents may be in electronic form. In this way, the two companies can easily exchange all the documents and information business (B2B). The cooperation with state institutions is possible in the same way (B2G). Through a variety of E-commerce solutions, customers and companies are connecting (B2C, CRM). There are several varieties of electronic payment: Versing, PayPal, Cash Online, etc. (Pocajt,V.,Tošić,D.,2003). 


\section{CONCLUSION}

Marketing concept as a most subtly business thread in one company, received support in the form of internet marketing. Part of the overall marketing in modern companies' approaches to deliver the value for customers and achieve competitive advantages which in the last decides has been focused on the online buyers. In fact, Internet marketing uses the approach that offers direct marketing that relies on the growth and development of telecommunications and information technology (IT).

Internet marketing, as a new form of marketing, includes all traditional activities (marketing research, promotion, distribution, sales), as well as two new activities such as offering content (Content providing) and enabling networking (Network).

Sale as sub-function of internet marketing or online sales is based on IT support, i.e. Internet technology. The main instrument of online sales is a well-designed web site, through which the whole process of online sales takes place. The key stages of the process are: presentation of products or services, sales negotiation, sales integration with storage and delivery, connections with other marketing activities and connections with other stakeholders in the electronic form.

Online sales negotiation includes personalization of sale or offer or recommendation to customers based on their profile, sales automation, dialogue with customers, twenty-four hour availability and different modalities of sales.

An indispensable aspect of online sales is the user service that provides online technical support and online training, support in different languages, legal support, feedback, etc.
For the success of online sales quality products and creative sales promotion activities (guarantees, the possibility of refunds; referrals of satisfied customers, etc.) are necessary. Online sales are supported by other online marketing activities. The Internet provides good opportunities to investigate the competition, since the companies can offer their quality products throughout the world. Also, the ability to promote products on the Internet (Internet advertising) is very important to support online sales.

Rich information products and low cost storage and transportation are suitable for online sales.

Online selling allows companies to create customer community. Online sales allow the payment by credit cards, with a pre-installed system for the secure electronic exchange of critical data, such as credit card numbers, customers' authorization codes and online financial transactions.

\section{LITERATURE}

Gašović, M. (2010). Menadžment Prodaje, Subotica: Ekonomski fakultet, pp. 240-249

Jović, M. (2012). Međunarodni marketing,Beograd: Intermanet, pp. 205-209

Kotler, Ph., Keller, K.L. (2006), Marketing Menadžment, XII izdanje, Beograd: Data status, pages 612-616

Mayer, D., Johnston, K., Eliis-Chandwich, F. (2000). Internet Marketing, New York, Prentice Hall, pp. 66-67

Milićević, V. (2002). Internet Ekonomija, Fakultet Organizacionih nauka, pp. 113-129

Pocajt,V., Tošić, D. (2003). Internet poslovanje posle 2000,Beograd: INI, p. 129

Siropolis, C.N. (2005). Menadžment malog preduzeća, Zagreb: Mate.pp. 65-75 